\title{
Effect of dietary chili pepper (Capiscum annum) supplementation on carcass characteristics, proximate composition and lipid profile of broiler chickens
}

Awodola-Peters, O. O., Yahaya, M. O., *Oganija, K. Y., Adetoro, B. O., Bolarinwa, M. O., Saka, A. A. and Akinyemi, A. O.

Federal College of Animal Health and Production Technology, Moor plantation, P.M.B

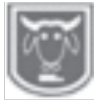

Abstract
5029, Ibadan Oyo state, Nigeria.

* Kwara State University, Malete, Kwara state

Corresponding author: ooawodolapeters@yahoo.com

Consumer awareness to quality poultry products and the ban and/or restricted use of antibiotic growth promoter has necessitated the use of natural alternatives. Chili pepper is a natural alternative that contain phytochemical compounds that exhibits pharmacological properties among others. While there are reports on the effects of dietary chili pepper as an antioxidant and antimicrobial, there are sparse information on its effect on carcass characteristics and quality of broiler chickens. A 7-week trial was conducted to assess the effect of dietary chili pepper (DCP) supplementation on the carcass characteristics of broiler chickens, proximate composition and lipid profile of the meat. Fresh chili peppers used were air dried, milled and stored in air tight container, and then supplemented into the experimental diets at varying levels of 0, 0.1, 0.2 and 0.3\% respectively to formulate four dietary treatments. One hundred and forty-four 1-old broiler chicks were randomly assigned into four treatment groups of 36 birds per treatments, replicated three times with 12 birds per replicate in a completely randomized design. The carcass characteristics of the broiler chickens were measured using two randomly selected birds per replicate. Meat samples collected from the breast, thigh and drumstick region were homogenized to determine proximate composition and lipid profile. Data obtained were subjected to analysis of variance. Results showed that the DCP supplementation had no influence $(p>0.05)$ on the carcass characteristics of broiler chicken measured. The DCP supplementation significantly $(p<0.05)$ influenced the proximate composition of the meat samples across dietary treatments. The dry matter, crude protein and ash contents of meat sample collected varied significantly $(p<0.05)$ across the dietary treatments as DCP supplementation increased. Birds fed on 0.1\% DCP-supplementation recorded the highest dry matter (29.93\%), crude protein (26.38\%) and ash (1.65\%) contents. The DCP supplementation significantly $(p<0.05)$ influenced the lipid profile of meat of broiler chicken across dietary treatments. Birds fed 0.1 and $0.2 \%$ DCP supplementation had the highest cholesterol values followed by those fed 0.3 and $0 \%$ DCP supplementation respectively. The triglycerides values of the meat sample increased across the dietary treatment as DCP supplementation increased. Birds fed $0.2 \%$ DCP supplementation recorded the highest high density lipoprotein $(16.83 \mathrm{mg} / \mathrm{dL})$ when compared with other means values. The low density lipoprotein values of the meat sample collected varied $(17.53-36.40 \mathrm{mg} / \mathrm{dL}$ ) significantly across the dietary treatments as DCP supplementation increased. It was therefore concluded that chili pepper can be supplemented at $0.1 \%$ in broiler chickens' diet to increase crude protein and inorganic contents of the meat and at $0.2 \%$ to improve lipid profile of broiler chicken meat.

Keywords: Chili pepper, broiler chickens, growth promoter, meat attributes, cholesterol 


\section{Effect of dietary chili pepper (Capiscum annum) supplementation}

\section{Effet de la supplémentation alimentaire en piment chili (Capiscumannum) sur les caractéristiques de la carcasse, la composition immédiate et le profil lipidique des poulets à griller}

\section{Résumé}

La sensibilisation des consommateurs aux produits avicoles de qualité et l'interdiction et/ou l'utilisation restreinte d'antibiotiques activateurs de croissance ont nécessité l'utilisation d'alternatives naturelles. Le piment est une alternative naturelle qui contient des composés phytochimiques qui présentent entre autres des propriétés pharmacologiques. Bien qu'il existe des rapports sur les effets du piment alimentaire en tant qu'antioxydant et antimicrobien, il existe peu d'informations sur son effet sur les caractéristiques de la carcasse et la qualité des poulets à griller. Un essai de 7 semaines a été mené pour évaluer l'effet de la supplémentation alimentaire en piment chili (APC) sur les caractéristiques de la carcasse des poulets à griller, la composition immédiate et le profil lipidique de la viande. Les piments frais utilisés ont été séchés à l'air, broyés et stockés dans un récipient hermétique, puis ajoutés aux régimes expérimentaux à des niveaux variables de 0, 0,1, 0,2 et $0,3 \%$ respectivement pour formuler quatre traitements diététiques. Cent quarante-quatre poussins de chair âgés d'un an ont été répartis au hasard en quatre groupes de traitement de 36 oiseaux par traitement, répliqués trois fois avec 12 oiseaux par réplicat dans une conception complètement randomisée. Les caractéristiques de la carcasse des poulets à griller ont été mesurées en utilisant deux oiseaux sélectionnés au hasard par répétition. Des échantillons de viande prélevés dans la région de la poitrine, de la cuisse et du pilon ont été homogénéisés pour déterminer la composition immédiate et le profil lipidique. Les données obtenues ont été soumises à une analyse de variance. Les résultats ont montré que la supplémentation en APC n'avait aucune influence $(p>0,05)$ sur les caractéristiques de la carcasse des poulets à griller mesurées. La supplémentation en APC a influencé de manière significative $(p<0,05)$ la composition immédiate des échantillons de viande à travers les traitements diététiques. La teneur en matière sèche, en protéines brutes et en cendres de l'échantillon de viande collecté variait considérablement $(p<0,05)$ selon les traitements diététiques à mesure que la supplémentation en APC augmentait. Les oiseaux nourris avec $0,1 \%$ de supplémentation en APC ont enregistré les teneurs les plus élevées en matière sèche $(29,93 \%)$, en protéines brutes $(26,38 \%)$ et en cendres (1,65\%). La supplémentation en APC a influencé de manière significative $(p<0,05)$ le profil lipidique de la viande de poulet à griller à travers les traitements diététiques. Les oiseaux nourris avec une supplémentation en APC à 0,1 et 0,2\% présentaient les valeurs de cholestérol les plus élevées, suivis de ceux nourris avec une supplémentation en APC à 0,3 et $0 \%$ respectivement. Les valeurs de triglycérides de l'échantillon de viande ont augmenté tout au long du traitement diététique à mesure que la supplémentation en APC augmentait. Les oiseaux nourris avec une supplémentation en APC à $0,2 \%$ ont enregistré la lipoprotéine de haute densité la plus élevée $(16,83 \mathrm{mg} / \mathrm{dL})$ par rapport aux autres valeurs moyennes. Les valeurs de lipoprotéines de faible densité de l'échantillon de viande prélevé variaient de 17,53 à 36,40 mg/dL de manière significative selon les traitements diététiques à mesure que la supplémentation en APC augmentait. Il a donc été conclu que le piment peut être complété à $0,1 \%$ dans le régime alimentaire des poulets à griller pour augmenter la teneur en protéines brutes et inorganiques de la viande et à $0,2 \%$ pour améliorer le profil lipidique de la viande de poulet à griller.

Mots clés : Piment, Poulets de chair, Promoteur de croissance, Attributs de la viande, Cholestérol 


\section{Awodola-Peters, Yahaya, Oganija, Adetoro, Bolarinwa, Saka and Akinyemi}

\section{Introduction}

There has been a recent trend that consumers avoid broiler chicken meat in their daily menu (Nasoetion et al., 2019). Several issues may bear such trend, some of which are antibiotic residues and high lipid content associated with broiler chicken meat. However, due to the emergence of microbes resistant to antibiotics, which are used to treat human and animal infections, the European Commission banned the use of antibiotics as growth promoters in animal nutrition. With regard to lipid content, consumers believe that broiler chicken meat may increase susceptibility to coronary heart disease and arteriosclerosis and if not addressed appropriately, the issue may negatively affect the sustainability of broiler chicken production (Nasoetion et al., 2019). Several alternate approaches for antibiotic growth promoters, including prebiotics, probiotics, organic acids, essential oils, medicinal plants or parts of plants such as thyme, basil, oregano have been identified (Puvaca et al., 2013), including capsaicin from the hot red pepper (Gnayfeed et al., 2001). Growth promoters are widely used in poultry because of their beneficial effects on feed conversion, growth and health of poultry birds, therefore there is increasing interest for the use of natural products such as plants, spices and plant extracts in animal feed (Puvaca et al., 2015). Chili pepper (Capsicum annum L.) is one of the most important spices widely used in human nutrition. In poultry nutrition, chili pepper has been added in small amount between 0.25 and $1.0 \%$ because of its important role in decreasing deposition of cholesterol and fat in the body which enhances declinein the triglycerides levels of the meat samples. Chili pepper was also reported to providesupport to the vascular system in the body (Puvaca et al., 2014). Hot red pepper is highly rich in vitamin $\mathrm{C}$, thus, has the potential of improving overall production through the decline of heat stress by influencing a considerable change in energy balance (Al-Kassie et al., 2012; Puvaca et al., 2015). Yoshioka et al. (1999) also reported that hot red pepper is rich in vitamin $\mathrm{C}$, with a considerable impact in improving production basically through its contribution thus reducing the heat stress. Chili pepper otherwise known as capsicum belonging to solanaceae family, thus, it is an economically important flowering plants and itis a fruit vegetable commonly used in human nutrition. Chili pepper contains high soluble phenolic compound which is higher than what is obtainable from other vegetables thus it is commonly recognized as a source of these substances. There are many properties that distinguish chili pepper from other fruit vegetables, thus includes shape, size, colour, flavour and heat, as they can be hot, sweet, fruity, earthy, smoky and floral (Puvaca et al., 2015). Varieties and stages of maturity also have great influence on chili peppers quality (Kumar et al., 2009). Poultry do not sense the effect of hot spices, either because of the lack of receptors specific for capsaicin binding (Mason and Maruniak, 1983) or the lack of receptors that are sensitive to capsaicin (Szolcsangi, 1976). On the other hand, capsaicin increases appetite in poultry, so the addition of hot red pepper to the diet influences feed consumption (Yoshioka et al., 1999). Effective compounds in hot peppers include;flavonoids, capsaicinoids and capsinoids; recent studies monitoring poultry performance showed that blends of the active compounds of hot red pepper resulted in chemo-preventive and chemotherapeutic benefits (Munglang and Vidyarthi, 2019). As seen for red chili peppers, capsaicin is the main active compound responsible for the pungent effects of various species of the hot red peppers (Jancso et al., 1997) and the main component including hot taste. Capsaicin 


\section{Effect of dietary chili pepper (Capiscum annum) supplementation}

has been shown to have a protective function in the gastric mucosa as a stimulant of afferent nerve endings. Although it is well known that plant extracts improve the digestibility of feeds in broiler chickens, Hernandez et al.(2004) reported that such ingredients only slightly improved performance, and these differences were not significant. However, this study is aimed at evaluating the effects of dietary chili pepper supplementation on the carcass characteristics of broiler chickens and proximate analysis as well as lipid profile of the meat.

\section{Materials and methods \\ Experimental site}

The experiment was carried out at the Teaching and Research farm of Federal College of Animal Health and Production Technology, Moor Plantation, Ibadan.

\section{Experimental birds}

One hundred and forty four (unsexed) broiler chicks were purchased from a reputable hatchery in Ibadan metropolis. The birds were raised on deep litter system with the floor covered with wood shavings and partitioned into different units. Vaccination and other routine medications were carried out as at when due. Fresh cool clean water was given ad libitum throughout the time of the study. The chicks were individually weighed and randomly allotted to four dietary treatments with three replicates of twelve birds each in a completely randomized design

\section{Duration of the experiment}

The experiment lasted for seven weeks.

\section{Source of chili pepper}

Fresh chili pepper was purchased at Oja Oba market, Ibadan Oyo State. It was air dried, milled and store in an air tight container. The dried milled chili pepper was then incorporated into the experimental diets at varying levels of $0,0.1,0.2$ and $0.3 \%$ respectively to formulate four dietary treatments.

\section{Experimental design}

The birds were randomly allocated into four dietary treatments consisting three replicates with 12 birds per replicate using complete randomized design.

\section{Experimental diets}

Complete feed that meets the dietary recommendations of the broiler chickens at different stages were purchased and equally allocated to the four treatments. Table 1 shows the nutrient composition of the starter and finisher basal diets fed to the broiler chickens.

Table 1: Nutrient composition of starter and finisher basal diets fed to the broiler chickens

\begin{tabular}{lll}
\hline Nutrient $(\%)$ & Starter diet & Finisher diet \\
\hline Protein & 21.00 & 19.00 \\
Fat & 2.75 & 2.85 \\
Fibre & 4.00 & 6.00 \\
Calcium & 1.00 & 1.00 \\
Available phosphorus & 0.45 & 0.45 \\
Energy (kcal/kg) & 2840 & 2875 \\
\hline
\end{tabular}

\section{Data collection}

At the end of the feeding trial, two birds per replicates were selected, weighed, slaughtered, bled, plucked and eviscerated. The primal cuts and internal organs were weighed. Carcass weight and parts of the birds were derived as relatives of live weight among the treatment groups. Meat samples were collected from the thigh, drumstick and breast regions, these were homogenized and the proximate composition and lipid profile assays were determined using standard procedures.

\section{Data analysis}

Data obtained were subjected to analysis of variance using SAS (2003) package; means were separated using Duncan's multiple range test of the same software. 


\section{Results}

Presented in Table 2 is the carcass characteristic of broiler chickens fed dietary chili pepper supplementation. Dietary chili pepper supplementation had no significant $(\mathrm{p}>0.05)$ influence on all the carcass characteristics measured.

Table 2: Carcass characteristics of broiler chickens fed

diets containing varying levels of chili pepper

\begin{tabular}{|c|c|c|c|c|c|}
\hline \multirow[b]{2}{*}{ Parameters } & \multicolumn{3}{|c|}{ Chili pepper supplementation } & \multirow[b]{2}{*}{$0.3 \%$} & \multirow[b]{2}{*}{ SEM } \\
\hline & $0 \%$ & $0.1 \%$ & $0.2 \%$ & & \\
\hline Live Weight(g/bird) & 1658.30 & 1796.20 & 1707.80 & 1469.30 & 72.80 \\
\hline \multicolumn{6}{|c|}{ Relative of Live weight (\%) } \\
\hline Carcass Weight & 61.49 & 64.25 & 65.24 & 63.08 & 1.46 \\
\hline Head & 2.86 & 2.80 & 2.87 & 2.82 & 0.09 \\
\hline Neck & 3.74 & 4.22 & 4.28 & 3.74 & 0.16 \\
\hline Shank & 5.41 & 4.38 & 4.88 & 4.65 & 0.25 \\
\hline Heart & 0.36 & 0.39 & 0.43 & 0.41 & 0.02 \\
\hline Wings & 9.08 & 7.73 & 7.93 & 8.23 & 0.27 \\
\hline Drum stick & 12.83 & 10.54 & 10.96 & 10.55 & 0.76 \\
\hline Breast & 15.75 & 18.53 & 19.55 & 18.71 & 0.50 \\
\hline Thigh & 10.58 & 10.82 & 10.17 & 11.21 & 0.36 \\
\hline Gizzard & 1.74 & 1.78 & 1.83 & 1.90 & 0.05 \\
\hline Spleen & 0.08 & 0.09 & 0.10 & 0.10 & 0.01 \\
\hline Abdominal fat & 0.43 & 0.55 & 0.50 & 0.58 & 0.12 \\
\hline Thymus & 0.13 & 0.19 & 0.18 & 0.22 & 0.02 \\
\hline Liver & 2.36 & 2.10 & 2.04 & 2.11 & 0.09 \\
\hline Back & 12.87 & 13.88 & 14.03 & 13.75 & 0.33 \\
\hline
\end{tabular}

SEM: Standard error of mean

Table 3 shows the proximate analysis of meat from broiler chickens fed dietary chili pepper supplementation. Result showed that chili pepper supplementation significantly $(\mathrm{p}<0.05)$ affected dry matter, crude protein and ash contents of the meat. Chicks on $0.1 \%$ DCP supplementation exhibited the highest dry matter value $(29.93 \%)$, crude protein $(26.38 \%)$ ether extract $(2.19 \%)$ and ash (1.65\%) while birds on $0.3 \%$ DCP supplementation had the lowest value in dry matter $(26.42 \%)$, crude protein $(23.10 \%)$ and ash $(1.28 \%)$ except ether extract.

Presented in Table 4 is the effect of dietary chili pepper supplementation on the lipid profile of the of broiler chickens meat. There were significant effects of chili pepper supplementation on lipid profile of meat of broiler chicken meat for all parameters measured. Highest cholesterol (73.45 mg/dL), Triglyceride (172.43 $\mathrm{mg} / \mathrm{dL})$ and high density lipoprotein (16.83 $\mathrm{mg} / \mathrm{dL}$ ) were obtained in meat from chickens fed $0.2 \%$ DCP supplementation while highest value of low density lipoprotein $(36.40 \mathrm{mg} / \mathrm{dL})$ was obtained in meat homogenates of broiler chicken fed diet containing $0.1 \% \quad$ D C P supplementation. Meat of broiler chicken that were not fed chili pepper have lowest level of cholesterol, triglyceride and low density lipoprotein while meat of birds fed $0.3 \%$ level of chili pepper had lowest level of high density lipoprotein. 
Effect of dietary chili pepper (Capiscum annum) supplementation

Table 3: Proximate Analysis of the meat of broiler chickens fed diets containing varying levels of Chili Pepper

\begin{tabular}{llllll}
\hline & \multicolumn{3}{l}{ Chili pepper supplementation } & \\
\cline { 3 - 5 } Parameters (\%) & $0 \%$ & $0.1 \%$ & $0.2 \%$ & $0.3 \%$ & SEM \\
\hline Dry matter & $27.95^{\mathrm{ab}}$ & $29.93^{\mathrm{a}}$ & $28.00^{\mathrm{ab}}$ & $26.42^{\mathrm{b}}$ & 0.54 \\
Crude protein & $24.56^{\mathrm{ab}}$ & $26.38^{\mathrm{a}}$ & $23.86^{\mathrm{ab}}$ & $23.10^{\mathrm{b}}$ & 0.48 \\
Ether extract & 2.01 & 2.19 & 1.88 & 2.04 & 0.08 \\
Ash & $1.34^{\mathrm{ab}}$ & $1.65^{\mathrm{a}}$ & $1.38^{\mathrm{ab}}$ & $1.28^{\mathrm{b}}$ & 0.06 \\
\hline
\end{tabular}

Table 4: Lipid profile of the meat of broiler chickens fed diets containing varying levels of Chili Pepper

\begin{tabular}{llllll}
\hline & \multicolumn{5}{c}{ Chili pepper supplemention } \\
\cline { 2 - 6 } Parameters & $0 \%$ & $0.1 \%$ & $0.2 \%$ & $0.3 \%$ & SEM \pm \\
\hline CHOL (mg/dL) & $49.47^{\mathrm{b}}$ & $73.03^{\mathrm{a}}$ & $73.45^{\mathrm{a}}$ & $70.58^{\mathrm{ab}}$ & 4.05 \\
TRIG(mg/dL) & $101.30^{\mathrm{b}}$ & $145.30^{\mathrm{ab}}$ & $172.43^{\mathrm{a}}$ & $159.20^{\mathrm{a}}$ & 9.44 \\
HDL (mg/dL) & $11.68^{\mathrm{b}}$ & $12.50^{\mathrm{b}}$ & $16.833^{\mathrm{a}}$ & $10.67^{\mathrm{b}}$ & 0.75 \\
LDL(mg/dL) & $17.53^{\mathrm{b}}$ & $36.40^{\mathrm{a}}$ & $24.38^{\mathrm{ab}}$ & $26.83^{\mathrm{ab}}$ & 2.59 \\
\hline
\end{tabular}

${ }^{\mathrm{a}, \mathrm{b}}$ means different superscript along the same roware significant different $(\mathrm{p}>0.05)$

CHOL.: cholesterol, TRIG.: means triglyceride, HDL: high density lipoprotein,

LDL: low density lipoprotein, SEM: standard error of mean

\section{Discussion}

Dietary chili pepper supplementation had no significant $(p>0.05)$ influence on all the carcass characteristics measured. Live weight ranged from the lowest value of $1469.30 \mathrm{~g}$ in birds on $0.3 \%$ DCP supplementation to the highest value of $1796.20 \mathrm{~g}$ in birds on $0.1 \%$ DCP supplementation. This agrees with the findings of Cardoso et al.(2011) who reported there was no significant difference $(\mathrm{P}>0.05)$ on carcass characteristics for broilers at 42 days of age when enzymatic complexes were used. This is also in line with the findings of Embrahimi et al. (2010), that the different feed particle size had no significant influence on eviscerated weight, dressed weight, thigh, breast, neck, head, while gizzard, lungs, back fat and bile. According to Hernandez et al. (2004), although ingredients such as chili pepper and other plant extracts have the potentials to improve digestibility of feeds and increase the weight gain, however, improved performance in terms of increased live weight and significant differences were not observed. Broiler chickens on $0.1 \%$ DCP supplementation exhibited the highest dry matter values $(29.93 \%)$, crude protein $(26.38 \%)$, ether extract $(2.19 \%)$ and ash $(1.65 \%)$ values while birds on $0.3 \%$ DCP supplementation recorded the lowest dry matter, crude protein and ash values. These values obtained were similar to the findings of Puvaca et al.(2016), this increment observed in the proximate values of the meat homogenates of broiler chicken used in this study can be attributed to the influence of capsaicin; the active compound in chili pepper enhancing the utilization of ingested feed. Many medicinal herbal products were reported to have potentials to reduce lipid and cholesterol in body and to enhance a safety profile. Theincrease observed in cholesterol levels of meat homogenates from broiler chickens fed dietary DCP supplementation agree with reports of Cavallini et al. (2009) which states that isoflavones failed to reduce 
cholesterol levels in hypercholesterolemic rabbits. Present study however does not agree with Fayed et al. (2011) who reported a significant decrease in cholesterol concentration in the lipid profile of breast and thigh muscles of broiler chickens fed diets supplemented with garlic powder, and with Eidi et al. (2006) that garlic extract significantly decreased the total cholesterol, triglycerides in diabetic rats. The highest concentration of HDL (12.50 and $16.833 \mathrm{mg} / \mathrm{dL})$ was recorded in treatments with addition of 0.1 and $0.2 \%$ chili pepper, respectively. The significant effect of chili pepper on the mean values of HDL compared to control and other treatments can be explained by the hypocholesterolaemic mechanism and the hypolipidemic action of chili pepper. Although results of this study indicate significant $(\mathrm{p}<0.05)$ increase of HDL by addition of chili peppers, there was also increase in concentration of LDL which does not agree with Kim et al.(2009) investigation which reported that this effect can be explained by the possible mechanism of antioxidant and antiperoxide lowering action on LDL or the decrease in hepatic production of very low density lipoprotein (VLDL) which serves as the precursor of LDL in the blood circulation. Results from this study corroborates the investigations of Ghaedi et al. (2014) where addition of pepper decreased triglycerides and total cholesterol while HDL was increased. Hot red pepper were reported to play an important role in decreasing the deposition of cholesterol and fat in the body, contributes to decreased levels of triglycerides and supports the vascular system in the body.

\section{Conclusions}

The study showed that dietary supplementation of chili pepper at $0.1 \%$ in broiler chickens diets improved protein and inorganic composition of broiler chicken meat, while, $0.2 \%$ supplementation of chili peppers increased high density lipoprotein also known as good cholesterol.

\section{Acknowledgements}

The authors wish to acknowledge the management of Federal College of Animal Health and Production Technology, Moor Plantation, Ibadan for the provision of an enabling environment in which this study was carried out.

\section{References}

Al-kassie, G. A. M., Ghassan, Y., Butris, S. J. A. and Ajeena, J. 2012. The potency of feed supplemented mixture of hot red pepper and black pepper on the performance and some hematological blood traits in broiler diet. International Journal of Advanced Biological Research 2:53-57.

Cardoso, D. M., Maciel, M. P., Passo, D. P., Silva, F.V., Reis, S. T. and Aiura, F. S. 2011. Effect of the use of enzymatic complex in diets for broilers.Arch. Zootech, vol.60, (232), pp.1053-1064.

Dibner, J. J. and Richards, J.D. 2005. Antibiotic growth promoters in agriculture: History and mode of action. Poultry Science 84: 634643.

Embrahimi, R. M., Bojar, P. S. and Mokhtar Z. 2010.Effect of feed particle Size On the performance and carcass characteristics of Broiler. Journal of Animal and Veterinary Advances. 9(10):14821484

Gnayfeed, M. H., Daood, H. G., Biacs, P. A. and Alcaraz, C. F. 2001. Content of bioactive compounds in pungent spice red pepper (paprika) as affected by ripening and 


\section{Effect of dietary chili pepper (Capiscum annum) supplementation}

genotype. Journal of the Science of

Food and Agriculture 81: 15801585 .

Hernandez, F., Madrid, J., Garcia, V., Orengo, J. and Megias, M. D. 2004. Influence of two plants extracts on broiler performance digestibility and digestive organ size. Poultry Science 85: 14661471 .

Jancso, G., Kiraly, E. and Jansco-gabor, A. 1997. Pharmacologically induced selective degeneration of chemosensitive primary sensory neurons. Nature 270: 741-743.

Mason, J. R. and Maruniak, J. A. 1983. Behavioral and physiological effects of capsaicin in red winged black birds. Pharmacology Biochemistry and Behavior 19: 857-862.

Munglang, N. N. and Vidyarthi, V. K. 2019. Hot Red Pepper powder supplementation diet of broiler chickens - A review. Livestock Research International, 7(3), pages 159-167.

Nasoetion M. H, Atmomarsono U., Sunarti D. and Suthama N. 2019. Growth performance and lipid profile of broilers fed different levels of purple sweet potato extract and raised under different stocking densities. Livestock Research for Rural Development. Volume 31, Article \#97. Retrieved, from

Puvaca, N., Stanacev, V., Glamocic, D., Levic, J., Peric, L., Stanacev, V. and Milic, D. 2013. Beneficial effects of phytoadditives in broiler nutrition. World's Poultry Science Journal 69: 27-34.

Puvaca, N., Kostadinovic, L. J., Ljubojevic, D., Lukac, D., Levic, J., Popovic, S., Novakov, N., Vidovic, B. and Đuragic, O. 2015
Effect of garlic, black pepper and hot red pepper on productive performances and blood lipid profile of broiler chickens. European Poultry Science 79: 113.

Puvaca, A.F., Kostadinovic, L.J., Popovic, B., Levic, J., Ljubojevic, C.V., Tufarelli, D.R., Jovanovic, E.T., Tasic, B.P., Ikonic, B and Lukac, A.A. 2016. Proximate composition, cholesterol concentration, and lipid oxidation of meat from chickens fed dietary spice addition (Allium sativum, Piper nigrum, Capsicum annum). en.engormix.com, accessed 30th July 2020.

SAS statistical package 2003. SAS ${ }^{2} /$ STAT Software, Release 9.0. SAS Institute, Inc., Cary, NC. USA.

Szolcsangi, J. 1976. On the specificity of pain producing and sensory neuron b 1 o cking effect of capsaicin. Symposium on Analgesics, Akademiaikiad, Budapest, pp. 167-172.

Yoshioka, M., St-pierre, S., Drapeau, V., Dionne, I., Doucet, E., Suzuki, M. and Tremblay, A. 1999. Effects of red pepper and caffeine consumption on energy balance in subjects given free access to foods. British Journal of Nutrition 80: 503-510.

Received: $6^{\text {th }}$ September, 2021 Accepted: $10^{\text {th }}$ December, 2021 